\title{
植物社会学的植生図の利活用と課題一その景観生態学への展開一
}

\author{
大野 啓一 * \\ 横浜国立大学大学院環境情報研究院 240-8501 横浜市保土ヶ谷区常盤台 79-7
}

\section{Applications of a phytosociological vegetation map and its role for development with landscape ecology Keiichi Ohno*}

Graduate School of Environment and Information Sciences, Yokohama National University, Tokiwadai, Hodogaya-ku, Yokohama, 240-8501 Japan

\begin{abstract}
Physiognomic and species compositional criteria that form a basis for correct use of the vegetation map are compared and discussed in this review. Systematizing classification systematizing of vegetation units was done by the criterion of species composition such as association would have not only a syntaxonomic attribute but also attributes of the synchorology, synmorphology and syndinamic. Moreover, description and understanding of an ecological characteristics of various attributes of each vegetation unit was necessary when the vegetation diagnosis and land evaluation were done from the vegetation map for which the phytosociological units were made as legends. However, it is not necessary for users to understand the ecological characteristics of vegetation units for effective use of the vegetation map. Ecological research related to classification of the patterns of vegetation landscape using the vegetation map are discussed further as the classification criterion of each vegetation complex in the symphytosociology or symphytocoenology developed from the phytosociology. Geosigmassociation is explained as a basic unit of vegetation landscape. Some results of the landscape ecological research related to the analyses of the spatial structure of vegetation landscape and of the interrelation are also shown.
\end{abstract}

Key Words: geosigmassociation, landscape ecology, phytosociological vegetation map, symphytosociology, vegetation landscape

要旨: 本総論では, 植生図の正しい利活用の基盤となる相観的基準と種組成的基準について比較・検討を行った. 群集など種 組成的基淮により分類体系化された植物社会学的植生単位には，階級的属性だけでなく，群落地理，群落形態，群落動態といっ た属性もあり，それらについても考慮する必要がある。また，植物社会学的植生単位を凡例として作成された植生図を利用し て植生診断や立地評価を行う場合, 植生単位がもつ様々な属性の生態的特質についての理解が必要なことを述べた. しかし, 植生図を利用する側が，植生単位がもつ生態的特質を必ずしも理解していないのが実情である. この問題は, 植生図の有効利 用を図るうえで解決すべき課題でもある。さらに本論では, 植生図を利用した植生景観の類型区分にかかわる景観生態学的研 究について論じた。すなわち, 植物社会学から発展した群植物社会学あるいは群植生学における植生複合単位の分類基準を示 すとともに, 植生景観の基本単位である総和群集区について解説した. また, 筆者らがこれまで行った, 植生景観の空間構造 や相互関係の解析にかかわる景観生態学的研究成果の幾つかを示した.

はじめに

ドイツでは戦前から国の研究機関を中心にして, 生態学に基づいた土地利用のための基礎図として植 物社会学的植生図がつくられている（宮脇 1968）. ドイツで発展した本格的植生図を日本に紹介し，か つ全国各地の植生図化を推し進めてきたのが宮脇昭

\footnotetext{
“連絡先 : k1ohno@ynu.ac.jp

受付: 2006 年 4 月 15 日/受理 2006 年 7 月 30 日
}

博士である. 博士は植生図の生態学的価值を論じた 総説（宮脇 1968）の中で, 「土地開発や利用, 自然 環境の保全や保護などの目的で立地の質を総合的に 評価する場合, 植生を生態指標とするのが最も確実 である、また, 多様な立地条件の総和に対応した植 生を分類し, 単位化して, それらの具体的な配分を 地図上に描いた植生図は，生命をもったものの側か らの立地評価図の役割を果たす」と記述している. このように, 植物社会学の研究成果の一つである植 生図は, 国土開発や地域計画, 土地利用計画のため 
の立地評価図としてだけでなく, 植生自然度の高い 植物群落の保全・保護, 動物の生息空間としての評 価・診断図, 景観区分の基礎図としても利用されて いる（宮脇 1968，1969）.

植生図を利用する場合，立地全体の質を総合的に 評価するのか，特定の生態的特質を明らかにするの かによって, 用いる植生図の種類が違ってくる.ま た, 評価対象の範囲の大きさによって植生図の縮尺 も異なってくる．植生図は，一定の分類基準に基づ いて識別された植生単位を凡例として作成される. 一方，このようにして作成された立地評価図として の植生図を有効活用するためには，植生や植生単位 を利用する側の十分な理解が前提となる．植生図に 描かれた植物群落とその配分を正確に把握すればす るほど, より科学的な植生の側からの立地評価が可 能となる.しかしわが国においては, 植生や植生単 位に関する理解が不十分なこともあり，土地利用の ための基礎図として植生図を有効に利活用している とは言い難い.

本論では，植生図の正しい活用の基盤となる植生 の分類基準を明確にするとともに，基準の一つであ る種組成に基づいて類型分類されるいわゆる植物社 会学的植生単位がもつ生態的属性情報について解説 する.またこのようにして識別された植生単位を 凡例として描いた植物社会学的植生図の利活用の事 例を紹介する.さらに，植物社会学的植生図を基図 とした植生景観の空間構造や相互関係の解析など, 群落複合単位あるいは植生複合単位の分類にかかわ る研究分野である群植物社会学による景観生態学的 研究への展開についても論じている.

\section{植生の分類基準と植生単位}

植生は，それ自体の形質を基準に類型区分される. このため, 植生の形質をどのように捉えるかによっ て, 把握される植生単位は様々である. また, 植生 のどの形質に基準をおくかによって, 識別される植 生単位およびそれに基づいて描かれる植生図の性格 が決まる，エーレンベルグ（Ellenberg 1956）は，現 存する植生の形質による分類基準として, 植生の外 観すなわち相観と，植生を構成する種の目録すなわ ち種組成をあげている．植生の相観的な基準として, 優占する特定の生活形または生育型, 階層構造, 季 節相などがあげられる: 一方, 種組成的な基準には, 1 種（例外として $2 \sim 3$ 種）によるものと, 一定の
種群によるものとがある. 前者はさらに, 優占種に よるものと高頻度種によるものに分けることができ る. また後者は, 統計的に把握される種群と統計に 拠らず確かめうる種群に分けられる. 統計的に得ら れる種群には, 恒存種群, 識別種群（区分種群とも いう), 標徵種群がある. 統計に無関係に得られる種 群には, 等しい生態的属性をもった種群, 等しい地 理的分布を持った種群, 等しい動態または遷移的な 意味の種群がある.

\section{1. 相観的植生単位としての群系}

植生の分類基準を相観においた場合, そこから導 かれる代表的な植生単位が群系である. グリ一ゼ バッハは, フンボルトが行った生物の分布と環境に 関する生態学的研究を基盤として,「草原, 森林な どのように, ある特定の生活形が優占し, 類似の相 観的特性をもち, 気候など同じような環境条件下で みられる一群の植物群落を指す上級の植生単位」と する群系の概念を明らかにしている（Schmithüsen 1959).リューベルは, この群系の概念を発展させ, 熱帯多雨林や照葉樹林などから成る樹林群系, 陸上 草原や水生草原などの草原群系といった相観的な植 生分類を行なっている（Schmithüsen 1959）.

世界の植生を体系的に類型区分する場合，相観的 植生単位としての群系が用いられる。一般的には, 熱帯から極地に向から気候帯に対応する, 熱帯多雨 林, マングローブ林, モンスーン林 (雨緑林), サバ ナ林, サバナ草原, ステップ草原, 荒原 (砂漠), 硬 葉樹林, 温帯常緑広葉樹林, 落葉広葉樹林 (夏緑林), 北方針葉樹林, ツンドラ, 寒帯荒原などの植生単位 が使われている，ちなみに，気候带と対応する相観 的植生単位を気候的極相という。また，その分布域 を植生帯という。このほか水中, 湿地, 砂丘など特 殊な場所あるいは土壤的条件に規定されて成立する いわゆる土地的極相の相観的植生単位として, 沈水 植生, 浮葉植生, ヨシ沼沢, 湿原林, スゲ湿原, 低 層湿原, 高層湿原, 砂丘植生などがある（Schmithüsen 1959).

\section{2. 群落分類単位 (階級的単位) としての群集}

分類基準を種組成においた場合，抽出される代表 的な植生単位として群集および群落がある．統計的 に得られる標徵種群や区分種群により識別される群 集・群落を基準に分類体系化された植生単位がいわ ゆる狭義の植物社会学的単位（階級的単位）である 
(Tüxen 1973 ; Tüxen and Kawamura 1975 ; 大野 1994 1999）。この群落分類単位の基本単位が群集である. 群集は，広域的な植生調查資料に基づいて作成され た組成表から抽出される植生単位で，「均一な立地条 件下に成立し，一様な相観と一定の種組成をもった 植物群落」のように定義づけられている．また群集 は, 広域的に特定の植物群落に対して適合度（BraunBlanquet 1964）の高い標徵種群および局地的にある 植物群落に対し, 相対的に適合度が高い区分種群に より規定される植生単位である。このように群集は， 組成表における統計的処理と適合度に基づいて抽出 される。これに対し群落は, 広域的な植生調査資料 により作成された組成表から抽出される群集とは異 なり，分布が局地的に限定され，かつ「区分種群」 により規定された植生単位である（Ellenberg 1956）.

群集の定義からも明らかなように，ほぼ同じよう な環境条件下では，ほぼ同じ生理・生態的能力を もった植物群落がみられる，同質の環境条件下には， 同じ種組成をもった植物群落が成立することを基本 に, 植生分類学あるいは植物社会学を植生の分析・ 評価の方法の一つとして学問的に体系づけたのがブ ラウン・ブランケ（Braun-Blanquet 1964）である. 彼がまとめた植生分類体系では, 群集の上位の植生 単位として，群集と同様に共有の標徵種群によって， 群団, オーダー, クラス等の上級単位に漸次まとめ られる. 一方, 群集以下の植生単位である亜群集, 変群集等は, 土地的および生態的環境要因によって 規定された区分種群により識別される.

階級的植生単位は, 種組成を基礎に, 植生の基本 単位である群集を明らかにし, 地球上に分布する全 ての植生の類型区分および体系化を研究課題の一つ としている. 種組成的に分類した階級的植生単位は, 生態学的観点からは環境指標として基準的な特性を もっている.すなわち,この植生単位を演繹的に用 いることで, 植生構造の解明だけでなく, 土壤の $\mathrm{pH}$, 無機塩類, 水分など立地環境の評価も可能にす る.

一般に，群集が成立する立地は，空閒スケール的 には微地形レベルあるいは小地形レベルに対応して いることから, 地域環境を微地形〜小地形レベルで 詳細に分析・評価するのに適している，例えば，関 東地方の南部を流れる河川の後背低地において, ゴ マギ - ハンノキ群集の分布する立地かムクノキ - エ ノキ群集の分布する立地かによって, その土地の地 下水位の高低や変動の多少を推定することができる
（Lei and Ohno 2004）。また，群集の下位単位である 亜群集や変群集を用いることによって, 微地形レべ ルでの立地環境の評価ができる，さらに，日本海側 と太平洋側の気候環境の腹背性（吉良ほか 1976）を 反映したチシマザサ - ブナ群団とスズタケ - ブナ群 団のように，上級単位である群団やオーダーを用い ることによって, 中気候以上あるいは中地形以上の 広域的な立地環境の評価も可能である.

\section{3. その他の植物社会学的植生単位}

チュクセンら（Tüxen 1973 ; Tüxen and Kawamura 1975）は，前述の階級的植生単位とは規範の異なる いわゆる広義の植物社会学的植生単位の存在を明ら かにしている（大野 1994，1999）。これらの植生単 位は，すでに述べた植生の分類基準でいえば，種組 成的基準の中の, 統計に無関係に確かめえる種群に あたる。

\section{（1）形態的植生単位}

形態的植生単位とは，植生の分類基準を種組成に おくが，統計処理によらずに確かめうるもののうち， 環境に対し等しい生態的要求をもった種群，いわゆ る生態群（Ellenberg 1956）により規定されるもので ある．また，植物群集を規定する種組成の変動では なく, 群集内部の微細な生育環境の違いに応じて変 動する優占種の植分をファシスというが，チュクセ ンほか（Tüxen and Kawamura 1975）はこのファシ スを形態的植生単位に位置づけている（大野 1994, 1999).

\section{（2）地理的植生単位}

地理的植生単位とは，植生の分類基準を種組成に おくが，統計処理によらずに把握されるもののう ち，等しい地理的分布をもった種群により規定され るものである. チュクセンら（Tüxen and Kawamura 1975）は，地史的変遷に起因する植物相の広域的あ るいは局地的な変動を反映した植生単位である地理 的族あるいは地方型や，高度分布型など分布高度の 違いによる群落内の種組成の変動を反映したものを 地理的植生単位としている（大野 1994，1999）。

\section{（3）動態的植生単位}

動態的植生単位とは，植生の分類基準を種組成に おくが，統計処理によらずに確かめうるもののうち， 等しい動態的または遷移的な意味をもった種群によ り規定されるものである。チュクセンら（Tüxen and Kawamura 1975）は，初期相あるいは先駆期など， 植生の発達段階や遷移系列上にみられる群落内の優 
占種の変動を表したものを動態的植生単位としてい る（大野 1994，1999）.

植生区分がより厳密, かつより詳細に規定される ほど，植生の空間的配分を描いた植生図の立地評 価図としての価值が高まる（宮脇 1968）。植生調査 資料をまとめた組成表において種組成により導かれ るのは, 統計的に得られる標徵種群や区分種群によ り識別される階級的植生単位だけではない. 場合に よっては, 統計に無関係に把握される植生単位も抽 出される. 従って, より厳密, かつ詳細な植生区分 を行なおうとすれば，階級的植生単位を基軸とし て, 形態的植生単位, 地理的植生単位, 動態的植生 単位を含めた多軸的な植生分類が必要となる（大野 1994, 1999).

\section{植生単位による空間区分}

群系や群集など，一定の分類基準に基づいて抽象 化された植生単位は，いずれもが分布する立地の生 態的特性を表現している。この植生単位の空間的分 布や配分を具体的に地図上に描いたものを植生図と いう（宮脇 1968）。植生図の種類は，植生単位の類 型概念に応じて様々である。このうち代表的な植生 図が，相観的植生図と植物社会学的植生図である. また植生図には, 図示される対象植生に応じて, 現 存植生図, 原植生図, 潜在自然植生図などがある（宮 脇ほか 1982)

\section{1. 相観的植生図}

常緑広葉樹林や落葉広葉樹林など相観に基づいて 類型区分された植生単位により描かれたものを相観 的植生図という，相観的植生図には，相観だけでな く種組成的分類基準の優占種を加えることが多い. この相観的植生図は，地球上の全域，またはアジ ア大陸というように地球的尺度（縮尺は $1 / 150$ 万〜 1/1,000 万）による広域的植生図の作成に有効である. また，相観的基準に優占種を加えた相観的植生図で は，縮尺 $1 / 2.5$ 万〜 1/100 万の中〜大縮尺での現存植 生の植生図化が可能である.

大縮尺の相観的植生図では，現地踏査による実際 的な植生把握の基礎の上に描かれるなど, その作成 方法は, 後述の植物社会学的植生に類似している. この植生図化法では，まず対象地の全域を踏査して， 植生単位を相観と優占種によって決定する. 次いで, 植生図化のための現地踏査を行う。 その際, 各植生
単位の具体的な広がりを空中写真によって検討す る. この場合, 現地および室内で空中写真像と各植 生の相観像を交互に比較・修正しながら植生図化を 進める. 大縮尺の相観的植生図は, 各植生単位の具 体的な配分が読み取れることから，厳密ではないが， ある程度の土地利用のための立地評価に役立つ（宮 脇 1968).

\section{2. 植物社会学的植生図}

種組成に基づいて分類されたいわゆる植物社会学 的植生単位により図化されたものを植物社会学的植 生図という（宮脇 1968 ; 宮脇ほか 1982）。この植 物社会学的植生図の凡例には, 局地的な植生調査に より識別される群落と, 広域的な植生調査に基づい て抽出される群集などの普遍化された植生単位があ る.

すべての植物社会学的植生単位は, その分布を規 定している気候, 地形, 土壌などの様々な環境因子 の総合的な特性を指標している。すなわち, 植物社 会学的植生単位の分布・配列を表した植生図をみる ことによって, 地域の立地環境の定性的および定量 的評価が可能である（宮脇 1968）。一般に, 群集以 下の下位単位により描かれる植生図は, 微地形レべ ルでのより詳細な立地評価が可能となる.すでに述 ベたように, 群団以上の上級単位で描いた植生図は, 中気候レベルあるいは中地形レベル以上の広域的な 環境評価に適しているが局地的な立地評価に適して いない。このため植物社会学的植生図は，群集ある いは下位単位レベルの凡例を用いた $1 / 500 〜 1 / 10$ 万 程度の大縮尺で作成されるのが一般的である.

植物社会学を基盤とする植生図は, 以下の工程で 作成される.まず，相観的植生図化法とほぼ同じよ うに対象地をくまなく踏査し，相観と優占種により 区分した植生単位を用いて全域の相観植生図を作成 する，その際，空中写真により各相観的植生単位の 広がりを修正する。この植生図化に並行して，す心゙ ての相観的植生単位を対象に植生調查を行なう。次 いで, 現地で得られた植生調査資料は持ち帰り, 室 内作業により群落組成表にまとめ局地的な群落単位 を決定する．さらに，類似した種組成をもつ各地の 群落を常在度にまとめ, 適合度に従って標徵種群お よび区分種群を抽出し，群集または，その上級単位 を決定する．同様に区分種群によって，亜群集以下 の下位単位も区分する，そして最終的に，群集ある いは下位単位レベルの植生単位により，相観的植生 
図から植物社会学的植生図に転換する.すなわち, 再度現地踏査を行い, 群落組成表に基づいて作成し た植生図凡例指針を用いて相観的植生単位から植物 社会学的植生単位に置き換える. 植生調查地点の密 度が高く, 相観的植生単位の境界が正確であれば室 内作業での変換も可能である. 一般に, 植生図化に 用いる植生単位が細かくなるほど, より詳細な立地 評価が期待できる.

\section{植生図の利活用と課題}

宮脇（1968）は，エーレンベルグ（Ellenberg 1963） の言葉を引用して植生図の利用価值を示している. すなわち, 「植生図は, 植物社会学者が各種の研究か ら得た成果を総合的な観点に立って, 一般の人にわ かる言葉に翻訳したものである」，相観的植生図にせ よ植物社会学的植生図にせよ, 植生図はいずれも立 地評価の指標として利用することができるが，同時 に適用範囲は限られており，限界がある，植生図を 立地評価に利用する場合, 立地全体の評価を求める のか，一部の特性について知ろうとするのか，どの 時点で評価するのかによって, どの植生図が最も適 しているかが決まる. また, 植生の分布範囲の大き さによって, 植生図の縮尺も異なってくる. 厳密で 詳細な立地評価を求めるのであれば, 群集以下の植 生単位を凡例として描くことのできる大縮尺の植生 図が望ましい，植生単位がより厳密に, より細かく 規定されるほど, また, その様な凡例で描かれた植 生図を正しく読み解くことができれば, より科学的 な自然診断や立地評価が可能になる（宮脇 1968）.

\section{1. 全国現存植生図の利活用と課題}

旧環境庁が実施した第 2 回（1978 年〜 1979 年） および第 3 回（1983 年〜 1987 年）の「自然環境保 全基礎調査・植生調査」において，わが国における 自然環境の基本情報図として $1 / 5$ 万現存植生図が全 国整備された。また, その時の植生調查要綱では, 「植 生図は, 国土計画, 地域開発, 産業立地等のための 自然診断図として, また自然保護・復元・維持のた めの生態学的処方箋として重要な基礎図であり, 各 種の保護ないし開発のマスタープラン作成に不可欠 な資料として高く位置づけられている. 先の第 2 回 植生調査では, 全国の植生の現況をより詳細に把握 するとともに，地域レベルの計画に対応できる植生 図を全国的に整備するための一環として, 植生調査
を実施し，縮尺 $1 / 5$ 万の現存植生図を作成する」と 謳っている. しかし, 作成された $1 / 5$ 万現存植生図 は必ずしも植物社会学的なものではなく, さらに各 都道府県によって精度に大きな相違が認められるも のであったことから，実際に植生図を利用する場合 に齟齝が生じるなど, 地域計画の基礎図として使い づらいものであった.

環境庁が環境省になってから新たに開始した第 6 回 (1999 年〜 2004 年)および第 7 回 (2005 年〜)の「自 然環境保全基礎調查・植生調査」では, 全国の植生 の現況を再度正確に把握し, 既往の $1 / 5$ 万現存植生 図の全面的な更新を目的として縮尺 $1 / 2.5$ 万による全 国現存植生図化がすすめられている．この縮尺 $1 / 2.5$ 万による全国現存植生図化では, 植生を全国的な観 点から整理し, 全国共通の凡例すなわち統一凡例を 設定している．この統一凡例の体系は，植生区分の カテゴリーを相観に基づく大区分, 優占種による中 区分，種組成による細区分の 3 段階に分けたもので ある. この凡例体系により, 各段階の植生単位の全 体での位置づけや他の凡例との関連が分かりやすく なった.この現存植生図を作成する際の凡例は細区 分の「群集」を凡例とするいわゆる植物社会学的植 生図化法を基本としている.ただし，「群集」が決 定できないものは優占種によって区分される「群落」 として暫定的に中区分に位置づけておくことになっ ている.なお, 第 7 回からは, 植生図の成果形態を GIS データ化および GIS 出力図化とし, 環境省の植 生調査情報提供ホームページ (http://www.vegetation. $\mathrm{jp} /$ ) で公開することになっている.また，旧環境庁 の時代を含め現環境省が実施した「自然環境保全基 礎調査・植生調査」および全国現存植生図化に関し ては，上記環境省ホームページに詳しく記されてい る.

全国現存植生図の精度を全国同じレベルにするた め, 環境省は縮尺 $1 / 2.5$ 万による全国現存植生図化 に際し, 全国レベルで統一する必要のある事項につ いて検討する会議・部会を設置した．また，部会の 一つである技術専門部会（凡例検討部会）において 全国現存植生図の利活用や課題に関する検討も行わ れている，そこでは，1/2.5 万の全国現存植生図の凡 例である群集レベルの植生単位がもつ生態的属性を 他の自然診断図や立地評価図に転化できるものとし て, 地域計画や土地利用のための基礎図だけでなく, 潜在自然植生図, 植生自然度図, ビオトープ図など の生態立地図や，環境保全・防災を目的とした生態 
機能図が挙げられている.

\section{2. 植生図の利活用に関するその他の事例}

筆者は，長年にわたる植物社会学的調査・研究あ るいは環境アセスメントにかかわり，日本各地の県 および市町村や尾瀬ヶ原や丹沢山地などの自然環 境保全地域等において各種の植生図を作成してきた (宮脇・大野 1972 ; 宮脇編 1975 ; 宮脇ほか 1984a，b， 1986a，b，1993; 大野 1996 ; 大野・尾関 1997). 作 成した植生図の多くは, 群集レベルあるいは亜群集 レベルの植生単位を凡例とする地域計画や土地利用 のための立地評価図あるいは自然診断図としての現 存植生図, 植生自然度図, 潜在自然植生図である。 これらの既発表資料を含め, 植物社会学的植生単位 と植生図にかかわる問題点について以下に記した.

\section{（1）形態的および動態的植生単位の図化}

大野・尾関（1997） は, 丹沢大山自然環境調査に かかわり, 丹沢山地の山地帯（ブナクラス域）の現 存植生図（縮尺 $1 / 2.5$ 万）を作成した. この現存植生 図では，オオモミジガサ - ブナ群集の組成表におい て階級的植生単位とは別に, 形態的あるいは動態的 植生単位である退行相を識別するとともに, 凡例と し図化している.この退行相に相当する林分は, 当 該群集の林床植生がシカの摂食や踏圧等の攪乱・破 壊により成立したものである。一部の研究者（遠山・ 坂井 1993）は，この林分をシカによる環境圧下に持 続・成立する一種の偏向遷移段階の植生単位として 新たな群集を提唱している. しかし, 林床植生の劣

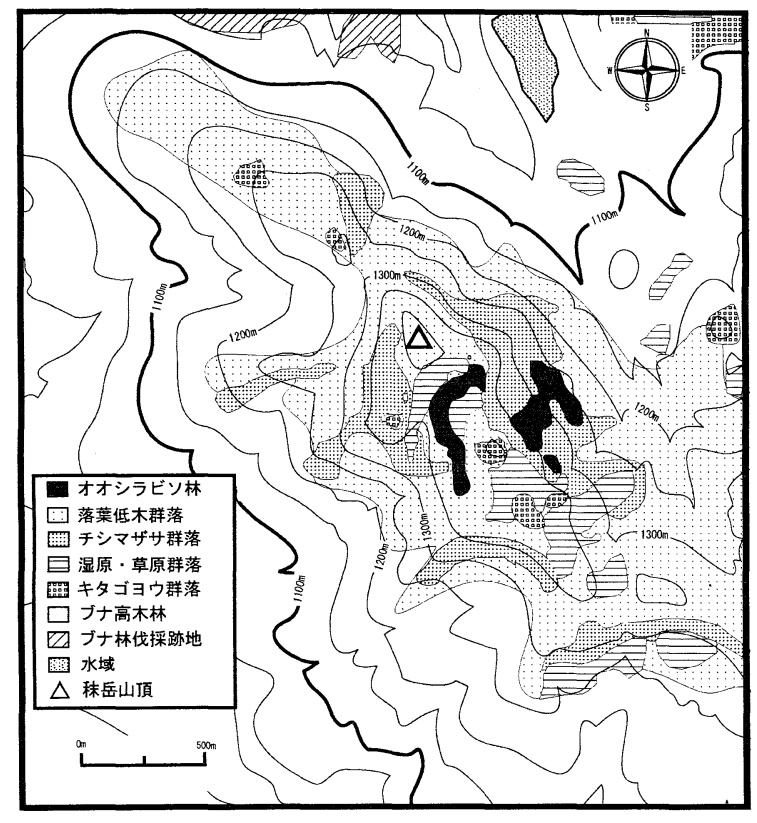

図 1. 秝岳山頂部の相観的植生図 (若松·菊池 2006, 原図). 凡例の植生単位については表 1 参照.
化が種組成の本質的な変化ではなく, 単に量的な変 動に起因すると考えられることなどから，攪乱を指 標する生態群の侵入・増加あるいは本来の種組成が 貧化・尔如した退行相と見なす方が妥当であろう。

このように，植生図化にあたっては，階級的植生 単位だけを凡例とするだけではなく, 形態的植生単 位や動態的植生単位の凡例を加えその意味を説明す ることによって, 対象植生の生態的属性に関する, より正確な評価が可能になる.

\section{（2）群落分類単位（階級的単位）の植生図化}

相観的植生図と植物社会学的植生図には, 類型区 分された凡例すなわち植生単位の空閒的な分布・配 列が同じように地形図上に描かれる. しかし, 両植 生図に表された植生単位の相互関係には大きな違い がある.すなわち, 前者では各植生単位の分布・配 列が個別に描かれているのに対し, 後者では群落組 成表により識別される階級的植生単位のほか, 形態 的植生単位や動態的植生単位など階層性や遷移動態 的関係等の生態的属性の明らかな植生単位の分布 配列が図示されている.

若松・菊池（2006）は, 秋田県栗駒山秝岳の山頂 部の相観的植生図を作成し, オオシラビソ林の成立 規定要因を論じている。この植生図（図 1）には, オオシラビソ林, 落葉低木群落, チシマザサ群落, キタゴヨウ群落など相観および優占種に基づいて類 型区分された各植生単位のモザイク状の分布が描か れている.また, この論文の常在度表（表 1）にも 植生図の凡例と同じ植生区分が示されている。この 表を見るかぎり，秝岳山頂部の植生は，チシマザサ， ミネカエデ，アカミノイヌツゲなどササ類と低木の 優占する植生域とヌマガヤ, イワカガミ, キンコウ カを主体とした湿原・草原植生域に大きく分けるこ とができる．また前者は，ナナカマド，ミヤマナラ が高頻度に出現する落葉低木群落とキタゴヨウ群落 に下位区分されている．この落葉低木群落はさらに, チシマザサ群落, キャラボクの混在する落葉低木群 落. オオシラビソ林に下位区分されている（表 1), すなおちこの表から，上記植生単位の間には上下関 係があり同じランクでないことがわかる．この植生 単位の上下関係から, 秝岳の山頂部は亜高山針葉樹 林が成立可能な気候環境下にあるが，そこを支配し ている主な植生は山地帯ブナクラスに所属するミヤ マナラ林であると推測される。 また，本地域にみら れるオオシラビソ林は, 亜高山針葉樹林を代表する オオシラビソ群集ではなく, ミヤマナラ林の下位単 
位として, 積雪が深く, 土壤厚の薄い立地に分布す る（若松・㐘池 2006）いわゆる土地的極相林（大場 1967）と考えられる. しかしこの論文では識別した 植生単位をすべて同じランクのものとして, 単位の 上下関係について考察していない。秝岳山頂部の植 物群落の分布構造を正確に表すためにも, 識別した 植生単位の階級的関係を示すなど，相観的植生図か ら植物社会学的植生図への転化が必要であろう。

上記の事例からも明らかなように, 群落組成表に おいて識別される区分種群には, 植物社会学的群落 体系に基づく各植生単位の階層性あるいは階級だけ でなく, 生態群やファシスのような群落の形態的属 性や先駆相や若齢期など群落の動態的属性をもつ場 合がある. 従って, 様々な生態的属性の明らかな植 生単位を区分した群落組成表に基づく凡例指針を用 いて描かれる大縮尺の植物社会学的植生図は, 植生 診断や立地評価だけでなく, 地域生態系の空間構造 および機能の解析に資する基礎図となる.

\section{植生図の利活用と群植物社会学}

群集など一定の種組成と相観をもち特定の立地環 境を指標する階級的植生単位や等しい生態的形質に より識別される生態的植生単位を凡例に描かれる植

表 1. 秝岳山頂部の植物群落常在度表（若松・菊池 2006, 一部改変)

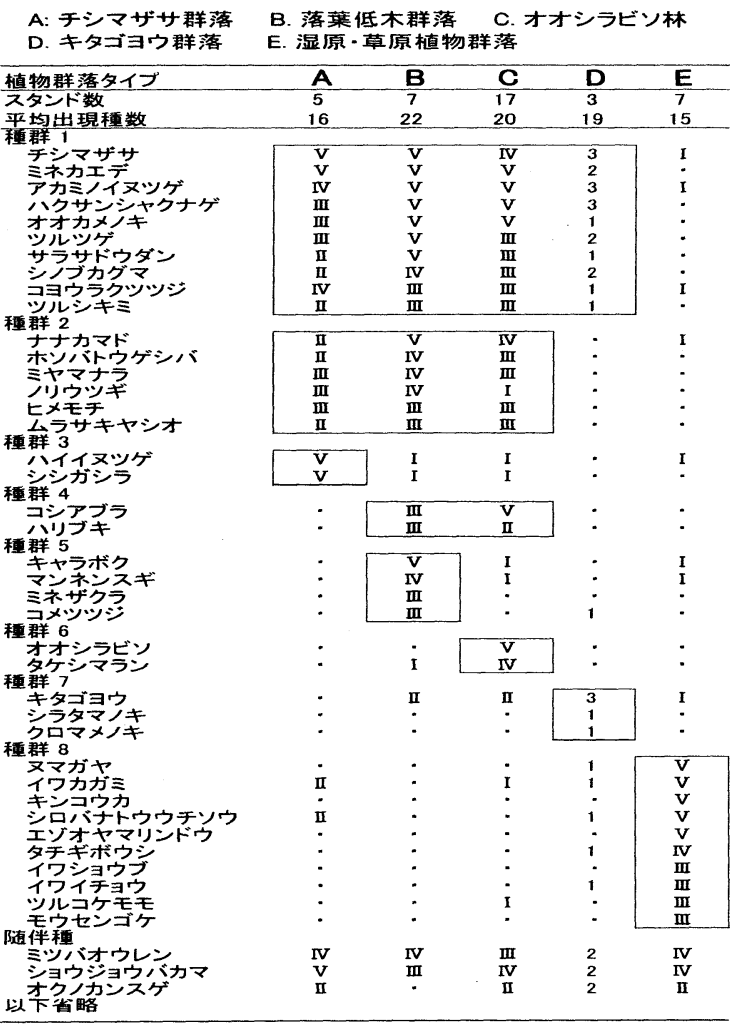

物社会学的植生図は, 地域生態系の空間構造や機能 を解析する上で重要な情報を提供する. しかし，こ のような生態的情報を内包した植生図の利活用は, 植生自然度図や潜在自然植生図への転化がせいぜい で, 植生図がもつ本来の能力を十分活かしきってい るとは思えない. そこで本項では, 地域生態系ある いは地域景観の主要な構成要素である植生の空間構 造や分布・配列パターンそして植生相互の機能的関 係の解明など，いわゆる景観レベルでの植生図の生 態学的分析・評価を可能にする群植物社会学とその 景観解析手法について解説する.

\section{1. 景観の分類基準と景観単位}

植生の場合と同様に，景観はそれ自体の形質を基 準に類型区分される．また，景観の形質をどのよう に捉えるかによって, 把握される景観単位は様々で ある。しかし，植生とは異なり，景観の分類基準と なる重要な形質は，外観的なものではなく，景観を 構成する各種要素である.この景観の主な構成要素 として, 無機的環境や有機的環境などの自然環境要 素と, 人間社会などの人文的環境要素があげられる. 一般に, 景観を区分する有効な形質として, 空間的 な類型化が容易な植生, 土壤, 地形がある。これら の自然環境要素を形質とすることによって, 景観の 構造および機能解析が可能となる.

気候, 土袞, 地形等の自然環境の総和を自然立地 という。この自然立地の空閒的広がりはある立地の 質の具体的範囲をいい，その性格をそこに表現し ているが，これを面的に広げ，地理的に均質な面す なわち等質地域としてとらえたものが基本的景観単 位としてのフリーゼと称する自然立地単位である (Schmithüsen 1959)。この自然立地単位とそこに生 育する生物共同体が機能的に結びついたものをエコ トープという（Schmithüsen 1959）. なお, 平野, 台地, 丘陵，山地等の地形単位は，エコトープを相観的に 特徵づけるとともに, 自然立地区分では地区を境界 づける中心的因子でもある.

シュミットヒューゼン（Schmithüsen 1959）は, 植 生景観を「景観の植生的要素であり，植生の集合」 と定義づけている．つまり，エコトープを構成する 生物共同体（ビオ・セノーシス）の一部である植物 共同体（フィト・セノーシス）は複数の植生単位の 集合から成る植生複合といえる。このことは, 植生 の複合単位により空間区分を行なうことによって, 植生の側からの景観の生態学的基本単位としてのエ 
コトープの分析・評価が可能であることを意味して いる. このように, 植物社会学的植生単位の集合で ある植生複合単位によりエコトープの空間構造およ び機能の分析・評価する研究分野が群植物社会学で あり群植生学である（Géhu 1991 ; Theurillat 1992). なお, 上記のエコトープは, 地理学分野の景観生態 学（横山 1995, 横山編 2002）で使用されている用語 とほぼ同じである.

\section{2. 群落複合単位の分類}

「潜在自然植生域における群落複合の調査に関す る研究」をテーマとして最初に群植物社会学的研究 を行なったのがチュクセン（Tüxen 1973，1978a，b） である. その後, 群植物社会学的研究分野において, 植物群落の集合の基本単位として総和群集（Béguin and Hegg 1975）の概念が提唱された。この総和群集 は，「均質で一定の景観において，それぞれの潜在 自然植生に対态して成立した現存植生の総体」とし て定義づけられた（Géhu 1974）。また, 総和群集は, 「一定の立地特性をもった地域において，規則的に繰 り返される植物群落の集合で, 従来の植物社会学に おける基本単位である群集と同様に, 識別種群に代 わり, 識別群落群によって導かれる」と考えられた (Tüxen 1979).

一方, リバスマルチネス（Rivas-Martinez 1976）は, 「生態的に均質な地域の部分であるテセラという限 られた区域の潜在自然植生に対応した代償植生の集 合」として群集群の概念を提唱した. その後, この 群集群は,「同じ潜在自然植生の領域にある総和群集 の一部」として定義づけられた（Rivas-Martinez and Géhu 1978)。また，ジェユーほか（Géhu and RivasMartinez 1981）は，「総和群集は，単一の潜在立地に おける同じ遷移系列のすべての植物群落の集合であ り，テセラはそれが分布する空間的領域」と定義づ けている，すなわち，テセラは等質地域あるいはエ コトープと同義であり, テセラ的領域に分布する総 和群集全体は, エコトープの一部であるフィトトー プと言うこともできる.

なお，総和群集（宮脇・鈴木 1979）はシグマ・ア ソシエイションの, 総和群落（山田・大野 2000）は シグマ・シンタクソンの日本語訳である。 また, 総 和群集は階級づけられた総和群落分類体系の基本単 位であり, 総和群落は階級づけされていない群落複 合単位である（表 2 : Theurillat 1992 および Dierschke 1994 を改変)。このように総和群集および総和群落
は, 微地形あるいは小地形レベルで同じ潜在自然植 生域にある, いわゆるテセラ的領域に分布する複数 の群集・群落から成る群落複合単位である（表 2).

\section{3. 植生複合単位の分類}

総和群集やエコトープは, 景観を等質地域に基づ いて類型区分するのに有効な空間単位であるが，複 数の異質な等質地域の集合で, 同じ生態的プロセス を生じさせる条件をもった空間的領域としての機能 地域の類型化に適していない. チュクセン（Tüxen 1978a，b）は，クナップ（Knapp 1975）が用いた地 総和群落分類群（ジオ・シンタクサ）を援用して, 植生景観の基本単位として地総和群集・群落を提唱 した. また, 地総和群集 (ジオ・シグマアソシエイショ ン）を「モザイク状あるいは帯状に関係しあった総 和群集の集合が，一つの広い地域において地理学的 秩序をもって繰り返す空間的領域」と定義づけてい る. カテナは,「空閒的な特徵をもつ配列が連続的に 繰り返される地形単位」を意味する用語であるが（松 井 1988), 地総和群集の定義に用いられているカテ ナは,「隣接するテセラの集合」を意味している. 従っ て, 地総和群集は,「総和群集の集合がカテナ状に分 布している空間的領域」と言い換えることもできる (Theurillat 1992).

なお，大野（1997）は，地総和群集分類体系の基 本単位である地総和群集を「総和群集区」と言い換 えている.また，複数の異なるエコトープの集合を 意味するエコトープ組織（横山 1995 ; 横山編 2002） と地総和群集あるいは総和群集区は同義語である (表 2)。このように, 地総和群集分類体系の基本単 位である地総和群集（総和群集区）と分類体系化さ れていない地総和群落（ジオ・シグマ・シンタクソ ン）あるいは総和群落区は, 微地形〜小地形レベル で機能的に関係した地域であるカテナ的領域におい て, 複数のテセラ領域に分布する総和群集あるいは 総和群落から成る植生複合単位である（表 2 ）.

\section{群落および植生複合単位に基づく景観区分}

ジェユー（Géhu 1991）は，総和群集の研究目的 を「植生系列の内容や遷移系列上の植生複合の組合 せを明らかにするもの」とし，地総和群集のそれを 「景観内部における植生複合間または遷移系列間の, あるいはそれらの集合が関係するカテナ的現象を分 析・評価するもの」としている。一方，トゥーリア 
（Theurillat 1992）は,「総和群集では, 遷移系列的基 準に基づいて，また地総和群集では，カテナ的基準 に基づいて, 植生景観を構成する植生複合単位が評 価される」としている.ささらに，「遷移系列的基準 では，テセラとマクロテセラの 2 段階のスケールで, また, カテナ的基準では, ヒポカテナ, カテナ, 八 イパーカテナ, メガカテナなど異なるスケールに対 応した 4 段階の植生複合単位（ヒポ総和群集区, 総 和群集区, 超総和群集区, メガ総和群集区）が把握 される」としている(表 2). すなわち, 景観を類 型区分する場合，遷移系列的基準やカテナ的基準の 様々な段階で, スケールの異なる植生複合単位によ り階層的に区分し，その分布・配列の特徵を表現す る必要がある.

景観の中の植生複合単位には，それらを表現する に相応したスケールがある。一般に，総和群集は， 大縮尺のスケールの地形図で, 地形単位でいえば微 地形から小地形レベルで表現される，一方，前述の 4 段階の単位区分をもつ総和群集区のうち, ヒポカ テナ的領域に分布するものは微地形レベルで, カテ ナ的領域では小地形レベル，ハイパーカテナ的領域 およびメガカテナ的領域では中地形レベルで表現さ れる（表 2).トゥーリア（Theurillat 1992）は, さら に上位のスケールである大地形レベルの植生景観単 位体系として, 接頭語にメソ, マクロ, メガ, ギガ, ホロを冠した総和群集地理区を提唱している (表 2).

\section{1．植生図を基盤とする景観区分}

植物社会学的あるいは相観的現存植生図を基図と して, 植生図化された地域を対象として, 当該地域 の植生景観を群植物社会学的手法により解析する研 究が北海道（大野 1990）および九州の大分市で行
われている（大野 1998）。これらの研究では，植生 図をメッシュ図化する，いわゆるメッシュ法あるい はグリッド法（大野・宮脇 1986 ; 大野 1989，1990， 1996，1998；Ohno 1991，1994，1997；宮脇ほか 1993 ；大野・山田 1998 ；山田・大野 2000）を用い ている，メッシュ図を作成するには，標準地域メッ シュ・システムに従い, 2 次メッシュあるいは3 次メッ シュで既存の植生図を機械的に区画する方法と，植 生図に描かれた凡例数（群落数）-面積曲線（Knapp 1975）により得られる適正サイズのグリッドで区画 する方法がある。いずれのメッシュ図においても植 物社会学的植生調査と同様に，区画した各グリッド を調查区として，グリッド内に出現する凡例（植生 単位）の被度・群度あるいは植被面積を求める。得 られたデータは植生景観区分表にまとめ，そこで表 操作を行い，総和群集区あるいは超総和群集区など 各種レベルの植生景観単位を識別する。この植生景 観区分表に基づいて，各グリッドが所属する植生景 観単位を特定し，その配置図を作成する。また，各 グリッドの地理情報や気象情報等の自然立地環境に 関する数值データはメッシュデータ化し，それに基 づいて各植生景観単位の生態的属性を明らかにす る.

北海道における研究（大野 1990）では，縮尺 $1 / 50$ 万の北海道現存植生図 (宮脇編 1989) を 2 次メッシュ 相当の $15 \times 15 \mathrm{~km}^{2}$ で区画したメッシュ図を作成し, 自然性の森林植生から成るメガ総和群落区相当の群 落団と超総和群落区レベルの群落亜団を識別してい る（表 3, 図 2)。なお, 群落団や群落亜団は, シュミッ トヒューゼン（Schmithüsen 1968）の植生複合単位体 系を援用したものである.また,トウーリア(Theurillat 1992）の単位体系との対応関係は，群落団はメガ総

表 2. 群植物社会学と地生態学の景観単位の対応関係(Theurillat 1992 と Dierschke 1994 を改変)

\begin{tabular}{|c|c|c|c|c|c|}
\hline $\begin{array}{l}\text { 地 形 } \\
\text { 単 位 }\end{array}$ & スケール & $\begin{array}{l}\text { 空間 } \\
\text { レベル }\end{array}$ & $\begin{array}{c}\text { 群植物社会学的分類 } \\
\text { 体系の基本単位 }\end{array}$ & $\begin{array}{c}\text { 景観単位の } \\
\text { 構成要素 }\end{array}$ & $\begin{array}{l}\text { 地生態学的景観単位 } \\
\text { (横山 1995よ変更) }\end{array}$ \\
\hline 微地形 & 大縮尺 & $\begin{array}{c}\text { テセラ的領域 } \\
\text { レベル }\end{array}$ & $\begin{array}{c}\text { 総和群集·群落 } \\
\text { マク口総和群集·群落 }\end{array}$ & $\begin{array}{l}a \\
a, b\end{array}$ & エコトープ \\
\hline $\begin{array}{l}\text { 小〜 } \\
\text { 中地形 }\end{array}$ & $\begin{array}{l}\text { 中〜 } \\
\text { 大縮尺 }\end{array}$ & $\begin{array}{c}\text { カテナ的領域 } \\
\text { レベル }\end{array}$ & $\begin{array}{c}\text { 上ポ総和群集区・群落区 } \\
\text { 総和群集区・群落区 } \\
\text { 超総和群集区·群落区 } \\
\text { メガ総和群集区・群落区 }\end{array}$ & $\begin{array}{c}a \\
a, b, c \\
{[a], b, c, d} \\
{[b], c, d}\end{array}$ & エコトープ組織 \\
\hline 大地形 & 小縮尺 & $\begin{array}{c}\text { 植生地理学 } \\
\text { レベル }\end{array}$ & $\begin{array}{l}\text { メソ総和群集·群落地理区 } \\
\text { マク口総和群集·群落地理区 } \\
\text { メガ総和群集·群落地理区 } \\
\text { ギガ総和群集·群落地理区 } \\
\text { ホロ総和群集·群落地理区 }\end{array}$ & $\begin{array}{l}\text { [b], [c], d } \\
{[c],[d], e} \\
e \\
e \\
e\end{array}$ & $\begin{array}{l}\text { ミクロコーレ } \\
\text { メソコーレ } \\
\text { マクロコーレ }\end{array}$ \\
\hline
\end{tabular}




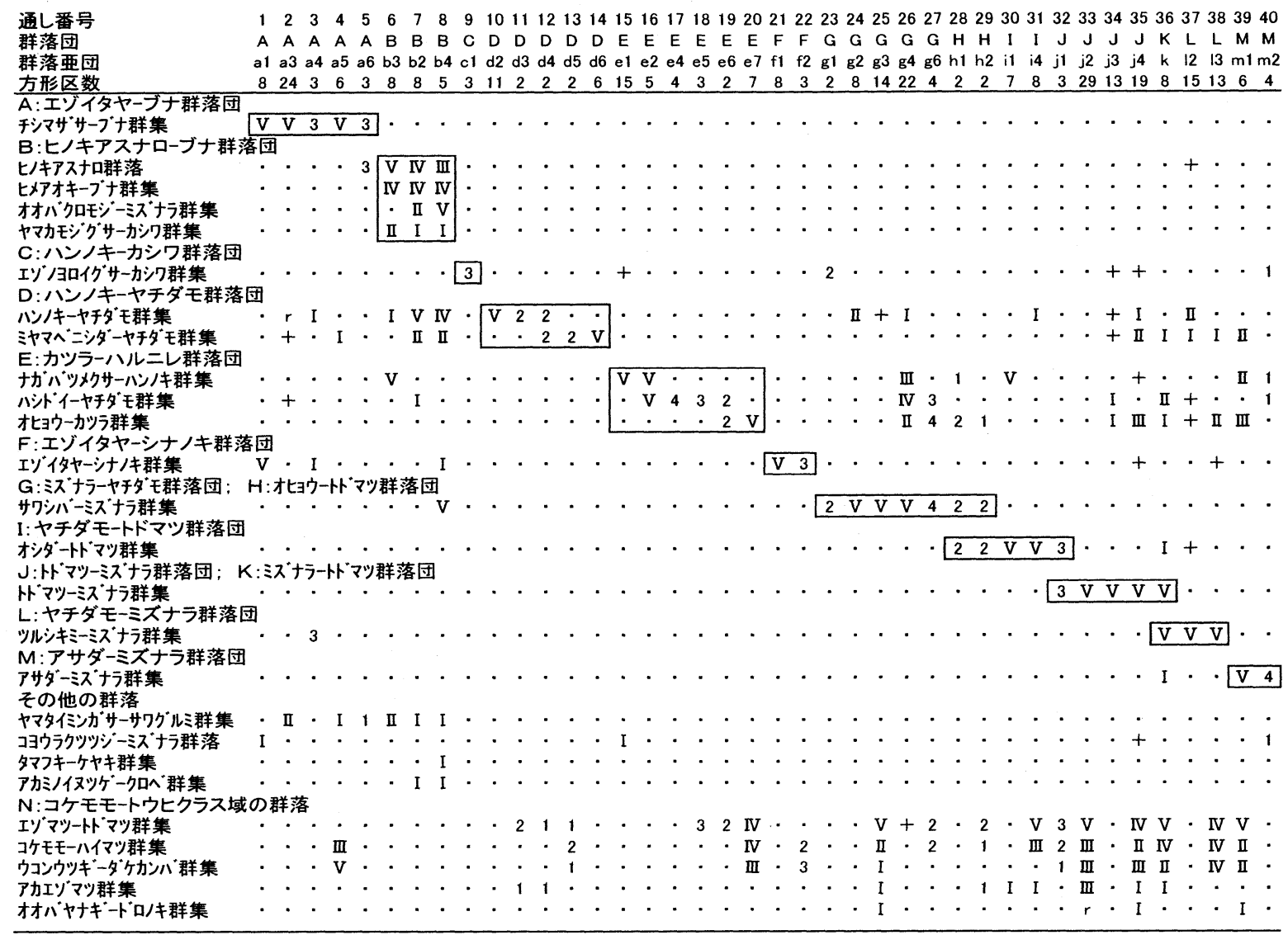

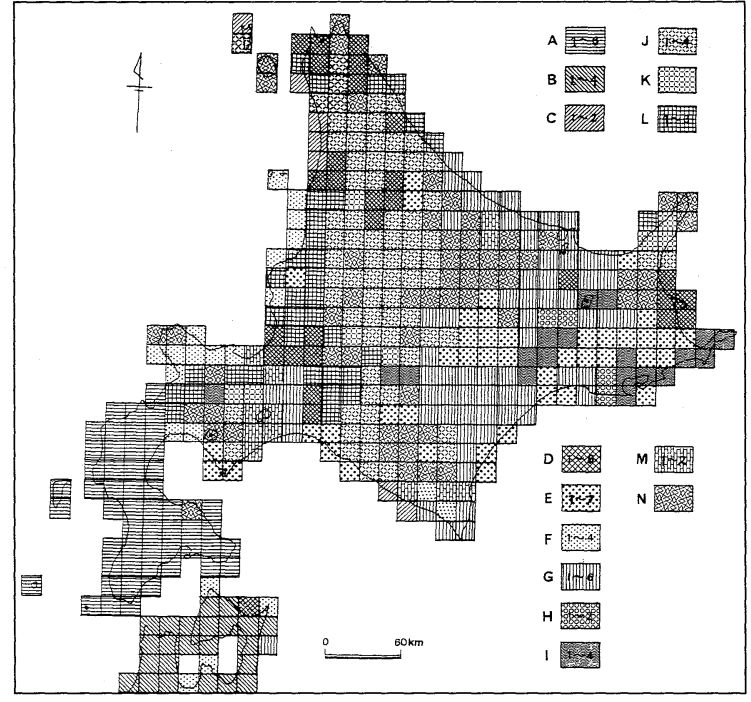

図 2. 北海道に抢ける群落団（表 3 参照）の分布（大野 1990, 原図。一部改変)。A：エゾイタヤーブナ群 落団, B : ヒノキアスナロ群落団, C : ハンノキーカ シワ群落団, D : ハンノキーヤチダモ群落団, E : カ ツラ - ハルニレ群落団, F : エゾイタヤーシナノキ群 落団, $\mathrm{G}$ : ミズナラ - ヤチダモ群落団, $\mathrm{H}$ : オヒョウ 一トドマツ群落団，I：ヤチダモートドマツ群落団，J： トドマツ -ミズナラ群落団, K : ミズナラ - トドマ ツ群落団, L : ヤチダモーミズナラ群落団, M : アサ ダーミズナラ群落団， N：コケモモ－トウヒクラス 域の植物群落.

和群集区に，群落亜団は超総和群集区に相当する．

宮脇編（1989）の作成した北海道の潜在自然植生
図と大野（1990）の潜在自然植生域区分図の大きな 違いは, 前者が北海道全域の沖積低地と台地・丘 陵地の潜在自然植生をそれぞれ同じ凡例で表してい るのに対し, 後者は, 福井（1933）が北海道の気候 環境を日本海側の西北海道地方と太平洋側およびオ ホーツク側の東北海道地方に区分したと同様に, 上 記地域を西北海道区と東北海道区にわけている点に ある（図 3）。このように植生複合単位に基づく景観 区分によって, 植生景観の階層性および地理的分布 レベルでの自然立地環境のより詳細な評価・区分が 可能となる.

九州の大分市における研究 (大野 1996, 1998) では, 現存および潜在自然植生図（共に縮尺 $1 / 3$ 万）と， 3 次メッシュ相当の $2 \times 2 \mathrm{~km}^{2}$ で区画したメッシュ図 に描いた総和群落区区分図や総和生態群区分図を重 ね合わせることにより，潜在自然景観域および生態 立地（エコトープ）の領域を特定するなど, 最終的 に生態立地図（エコトープマップ）の作成を行って いる.この生態立地図は, 地域の潜在自然や環境特 性に適合・調和した個性的な緑, すなわち「郷土の緑」 を保護・保全し, その復元・再生を可能にする植生 生態工学に基づいた環境保全計画や緑化計画を実施 


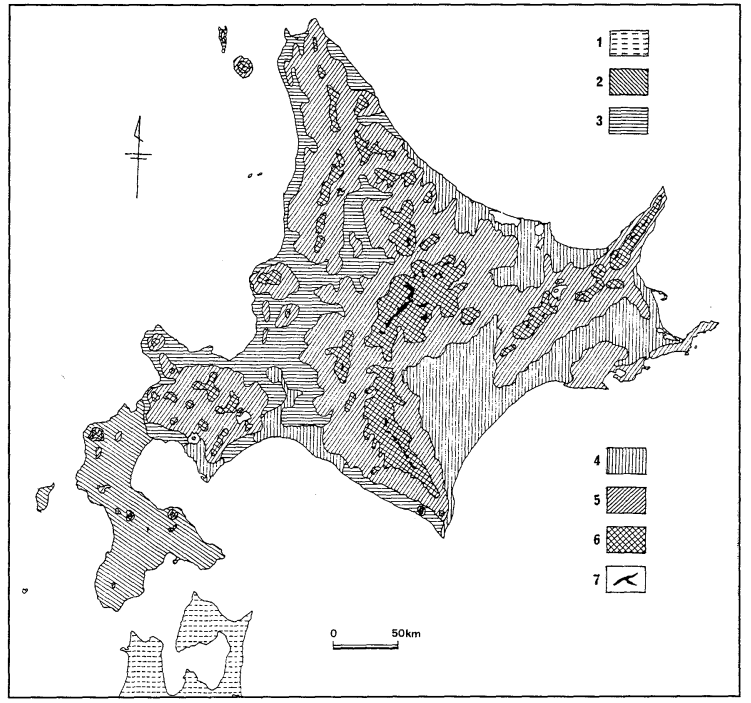

図 3. 北海道における潜在自然植生域区分図（大野 1990, 原図. 一部改変） 1 : 中部冷温帯业域・本州北区，2: 中部冷温帯亜域・渡島半島区, 3 : 北部冷温帯亜域 西北海道区，4:北部冷温帯业域・東北海道区，5 山地性冷温帯亜域, 6 : 亜高山性冷帯亜域, 7 : 高山 性寒帯亜域.

するうえでの基本的な設計図となる（大野 1998）.

上述のいずれの研究も群落抢よび植生複合単位を 用いて植生図を分析・評価する手法が植生景観の階 層構造の解析に有効であることを示している. しか し, 景観生態学の主要な研究課題である景観の空間 構造の解析と景観単位の成立・分化にかかわる生態 的プロセスを解明するうえで, 群植物社会学的解析 手法は十分でないと考えられた，また，大野（1998） の生態立地図は, 本質的には潜在自然植生立地図で あり，そこには一切野生動物との生態学的関係が考 慮されていないなど, 本当の意味でのエコトープ マップとは言い難い一面もある.

\section{2. 群植物社会学的植生図に基づく植生景観の解析}

矢内ほか（現在，查読論文として投稿中）は，植 物社会学的植生図ではなく, 総和群集・群落や総和 群集区・群落区など群落および植生複合単位を凡例 とする群植物社会学的植生図を基図として, 植生景 観の組成・構造や分布・配列パターンの解析, 景観 単位の成立・分化にかかわる生態的プロセスの解明 を目的とした景観生態学的研究を行なっている.

この研究では, 既往の植生図は使用せず, 植生調 查の場合と同様に, 調查区域をくまなく踏查し, 微 〜小地形レベルで区分されるテセラ的領域および カテナ的領域に分布するすべての植物群落をリスト アップするいわゆる植生景観調查を行なう。これに より得られた調査票を総和群落組成表にまとめ, 表
操作により総和群集・群落および総和群集区・群落 区等の各種植生景観単位を識別する。次に, 従来の 植生図化と同椂に，識別した植生景観単位を凡例と して植生景観区分図を作成する。この段階で,グリッ ド法により植生景観区分図を区画するとともに，一 つのグリッドを調查区として植生景観調查を実施 し, その結果を統合植生景観区分表および統合植生 景観常在度表にまとめる.この統合植生景観常在度 表において得られる植生景観単位は, 複数の異質な 総和群落区の集合体としての超総和群落区である. すでに述べたように，この超総和群落区が分布する ハイパーカテナ領域のスケールは小〜中地形レベル に相当する（表 2)，統合植生景観常在度表に基づい て, 各グリッドが所属する統合植生景観単位として の各種レベルの超総和群落区を特定し, その配置図 すなわち統合植生景観評価図を作成する，このよう にして図化された植生景観区分図や統合植生景観評 価図はともに群植物社会学的植生図である.

総和群集・群落あるいは総和群集区・群落区など の植生複合単位には階層性あるいは階級があり, 植 生景観単位の上下関係や分布領域のサイズの大小に よって, 地域植生景観を特徴づけているマトリック スやパッチなどの植生景観の空間構造や分布・配列 を明らかにすることができる，また，植生景観単位 を構成する植物群集・群落など各種植生景観要素の 様々な生態的属性（例えば自然度）に基づいて，そ の特質や成立にかかわる要因およびプロセス等の解 明が可能である。このように, 群植物社会学に基づ く植生景観単位の識別とそれを凡例として描かれる 群植物社会学的植生図は, 植生景観の組成・構造や 分布・配列パターンの解析, 景観単位の成立・分化 にかかわる生態的プロセスの解明など，いわゆる景 観生態学的研究に有効と考えられる.

群植物社会学的植生図のメリットは表現できるス ケールが微地形レベルから大地形レベルまで広いこ とである。従来の植物社会学的植生図では, 群集・ 群落を凡例にして図示できるスケールは，せいぜい 縮尺 $1 / 100$ 万程度と考えられるが，それ以上の小縮 尺で作成される植生図は, 群団やオーダーレベルの 植生単位を凡例とする潜在自然植生図や相観的植生 図が一般的である. 一方, 総和群集区や超総和群集 区などテセラあるいはカテナ的領域レベルの，さら には総和群集地理区など植生地理学レベルの景観単 位を凡例にして作成される群植物社会学的植生図で は，縮尺 1/100 万〜 1/1000 万の小縮尺においてもよ 
り詳細な自然立地環境の違いが表現できる.

\section{おわりに}

本論の前半では, 様々な分類基準で類型区分され た各種植生単位の具体的な広がりを地形図上に描い た植生図の利活用にかかわり, 詳細な立地環境の分 析 - 評価や人為的干涉の度合が表現可能な植生図と はどのようなものか明らかにした，立地環境の生態 的特質を表現できる植生図の一つとして，種組成的 基準に基づいて分類される植物社会学的植生単位で ある群集・群落を凡例に描かれる植物社会学的植生 図をとりあげ，その生態指標としての有効性を論じ た。すなわち, 植物社会学的植生単位には分類体系 上の階級だけでなく, 形態的特性, 地理的分布特性, 動態的特性など様々な生態的属性をもっている.こ のように, 植物社会学的植生単位に基づいて描かれ た植生図は，植生の側からの総合的かつ客観的な立 地環境の分析・評価が可能なことから，林業や農業 などの土地利用だけでなく, 国土開発や地域計画を 立案・策定する際に，自然環境の保全・管理のため の基礎図となる。しかし，この植生図を利用する側 が，植生に関する十分な知識と理解する力がなけれ ば，植物社会学的植生図を正しく読み取り，多様な 立地環境を正確に分析・評価するのは難しい. 従っ て，植生図の利活用には，植物社会学的植生単位の 階層性や生態的属性を十分理解し，その分布・配列 を描いた現存植生図が示す環境情報が何であるかを 把握する能力が前提となる.さらに，この植生図を 利用者の目的に沿った各種転化図に置き換えること で，はじめて適切な利活用が可能と考えられる.

本論の後半では, 総和群集・群落や総和群集区・ 群落区などの植生景観単位を凡例にして描かれ，か つ地域の立地環境の景観スケールでの分析・評価が 可能な群植物社会学的植生図について紹介した. 群 植物社会学の分類体系に基づいて類型区分される植 生景観単位は, 植物社会学的植生単位と同様に階層 性や植生自然度等の生態的属性をもつ。このことか ら，植生景観単位を凡例として描かれる群植物社会 学的植生図は, 植生景観の空間構造の解析や景観単 位の成立・分化にかかわる生態的プロセスの解明な ど，いわゆる景観生態学的研究に有効であることを 明らかにした。この群植物社会学的植生図の場合も, 生態学的に価値のある植生図を作成するためには, 自ら植生景観調查を行ない, 得られた調査資料を群
落複合組成表にまとめ, 植生景観単位を識別し，そ れらを体系づける必要がある。ささらに, 類型区分し た景観単位の階層性や生態的属性を明らかにし，そ れらを植生図に反映させなければならない。

このように植物社会学的あるいは群植物社会学的 植生図のいずれの場合も，この種の植生図を有効に 利活用するには, 植物社会学および群植物社会学 をマスターした人材が必須である. それ故, 植物社 会学および群植物社会学に関する基礎的な知識をも ち，植生図化にかかわる一連の解析手法を使いこな せる人材を育成するためのプログラムを実社会に提 供する責務も我々研究者に課せられている.

\section{引用文献}

Béguin, C. and Hegg, O. 1975. Quelques associations d'associations (sigmassociations) sur les anticlineaux jurassiens recouverts d'une végétation naturelle potentialle (essai d'analyse scientifique du paysage). Documents Phytosociologiques 9-14: 9-18.

Braun-Blanquet, J. 1964. Pflanzensoziologie. Grundzuge der Vegetationskunde. 3.ed. 865pp. Springer, Wien/New York.

Dierschke, H. 1994. Pflanzensoziologie. Grundlagen und Methoden. 683pp. Ulmer, Stuttgart.

Ellenberg, H. 1956. Aufgaben und Methoden der Vegetationskunde. Einführung in die Phytologie $(\mathrm{H}$. Walter ed.), 1-136. Ulmer, Stuttgart.

Ellenberg, H. 1963. Vegetation Mitteleuropas mit den Alpen. 943pp. Ulmer, Stuttgart.

福井英一郎 1933. 日本の気候区. 地理学評論 9: 1-37, 108-127, 195-219, 271-300.

Géhu, J.-M. 1974. Sur l'emploi de la méthode phytosociologique sigmatiste dans l'analyse, la définition et la cartogramphie des paysages. C. R. Acad. Sc. Paris 279: 1167-1170.

Géhu, J.-M. 1991. L'analyse symphytosociologique et géosymphytosociologique de l'espace. Théorie et méthodologie. Colleques Phytosociologiques 17: 11-46.

Géhu, J.-M. and Rivas-Martinez, S. 1981. Notions fundamentals de phytosociologie. Bericht Internationale Symposium, Internationale Vereinigung Vegetationskunde (1980) 5-33. Cramer, Vaduz.

吉良竜夫 - 四手井綱英 - 沼田真 - 依田恭二. 1976. 日 本の植生 . 科学 46: 235-247. 
Knapp, R. 1975. Zur Methodik der Untersuchung von Gesellschaftskomplexen mit Beispielen aus Hessen und Afrika. Phytocoenologia 2: 401-416.

Lei, Y. and Ohno, K. 2004. Ecological studies on Japanese alder (Alnus japonica) forests in southern Kanto Plain, central Japan-Syntaxonomy and correlateion between the growth traits of several vegetation units and ground water. Hikobia 14: 197-210.

松井健. 1988. 土㙥地理学序説. 316pp. 築地書館, 東 京.

宮脇昭. 1968. 植生図の類型と立地評価. 地図 6(2): 1-9.

宮脇昭. 1969. 自然の保護と植生図. 山と博物館 14(6): 2-3.

宮脇昭.（編）1975. 富山県現存植生図. 富山県 .

宮脇昭. (編) 1989. 日本植生誌 9. 北海道. 563pp. 至文 堂, 東京.

宮脇昭 - 藤原一繪 - 大野啓一・鈴木伸一. 1984a. 尾 瀬の植生 . 横浜植生学会 48: 1-60.

宮脇昭・飯村優子・鈴木邦雄 . 1982. 植生による環境 立地の診断. 土木工学体系 3. 自然環境論（II）（土 木工学体系編集委員会編）, 35-68. 彰国社, 東京.

宮脇昭・大野啓一. 1972. 若葉台団地建設予定地区・ 植物社会学的研究調查報告. $44 \mathrm{pp}$. 神奈川県住宅供 給公社, 横浜。

宮脇昭 - 大野啓一・藤原一繪 - 林寿則 - 北山雅弘 原田洋. 1993. 内子町の植生. 122pp. 内子町（愛媛 県).

宮脇昭 - 大野啓一 - 中村幸人 - 村上雄秀 - 鈴木伸一。 1984b. 若狭湾沿岸地域の植生. 横浜植生学会 47: $1-236$.

宮脇昭・大野啓一・鈴木伸一・仲田栄二.1986a. 北 谷町の植生. $153 \mathrm{pp}$. 北谷町（沖縄県）.

宮脇昭 - 奥田重俊 - 大野啓一・鈴木伸一. 1986b. 下 北半島および亀田半島南部の植生. 横浜植生学会 50: 1-157.

宮脇昭・鈴木邦雄 . 1979. 榛名地区の総和群集一植物 社会学的景観区分. 上越新幹線建設に伴う環境調 查研究報告書, 97-127. 東京.

大場達之. 1967. ミヤマナラ林. 宮脇昭 (編). 原色 現代科学大事典 3. 植物. 364-365. 学研, 東京.

大野啓一. 1990. 北海道 (北部日本) における植生域 の評価・区分に関する植生生態学的研究 . 横浜国 立大学環境科学研究センター紀要 16: 197-215.

Ohno, K. 1991. A vegetation-ecological approach to the classification and evaluation of potential natural vegetation of Fagetea crenatae region in Tohoku (northern Honshu). Ecological Reserch 6: 29-49.

Ohno, K. 1994. A symphytosociological approach to the evaluation and classification of the potential natural vegetation regions in Shikoku, southwestern Japan. Colloques Phytosociologiques 23: 77-94.

大野啓一. 1994. 森林群集の分析に係わる研究一植物 社会学から.森林科学 10: 24-27.

大野啓一. 1996. 大分市の植生. 114pp. 大分市.

大野啓一. 1997. 景観生態学の基盤としての群植物社 会学の理論と方法論. 横浜国立大学環境科学研究 センター紀要 23: 127-137.

Ohno, K. 1997. Symphytosociological studies on vegetation-landscapes in the Fagetea crenatae region of the Tanzawa mountains of Kanagawa Prefecture in Honshu, Japan. Colloques Phytosociologiques 27: 829-850.

大野啓一. 1998. 大分市の植生景観と生態立地図。 39 p. 大分市.

大野啓一. 1999. 多次元的群落分類のすすめ. Actinia 12: $95-102$.

大野啓一・宮脇昭. 1986. 本州中部山地帯の森林群落 に関する植生地理学的研究. Hikobia 9: 417-429.

大野啓一・尾関哲史. 1997. 丹沢山地の植生 (特にブ ナクラス域の植生について). 丹沢大山自然環境総 合調查報告書, 103-121. 神奈川県, 横浜.

大野啓一・山田麻子. 1998. 植生景観の解析に用いる メッシュ方形区のサイズに係わる研究. 横浜国立 大学環境科学研究センター紀要 24: 49-59.

Rivas-Martinez, S. 1976. Sinfitosociologia, una nueva metodologia para el studio del paisaje vegetal. Anales Inst. Bot. Cavanilles 33: 179-188.

Rivas-Martinez, S. and Géhu, J.-M. 1978. Apport de l'excursion de l'assciation amicale francophone de phytosociologie à la connaissance des synassociations de l'étage subalpin du Valais Suisse. Bericht Internationale Symposium, Internationale Vereinigung Vegetationskunde (1977), 151-159. Cramer, Vaduz.

Schmithüsen, J. 1959. 植生地理学 (シュミットヒュー ゼン著, 宮脇昭訳, 1968). 307pp. 朝倉書店, 東京.

Theurillat, J. -P. 1992. Etude et cartographie du paysage végétal (symphytocoenologie) dans la région d'Aletsch (Valais, Suisse). 398pp. Thése de doctorat és Sciences, Universite de Bern. 
遠山三樹夫・坂井敦. 1993. 神奈川のブナ林. かなが わ森林財団報告書，1-60. (財) かながわ森林財団， 横浜.

Tüxen, R. 1973. Vorschlag zur Aufnahme von Gesellschaftskomplexen in potentiellen natürlichen Vegetations gebieten. Act. Bot. Acad. Sci. Hungaricae, Tomus 19: 379-384.

Tüxen, R. 1978a. Bemerkungen zur historischen, begrifflichen und methodischen Grundlagen der Synsoziologie. Bericht Internationale Symposium, Internationale Vereinigung Vegetationskunde (1977), 3-11. Cramer, Vaduz.

Tüxen, R. 1978b. Versuch zur Sigma-Syntaxonomie mitteleuropüischer Flusstal-Gesellschaften. Bericht Internationale Symposium, Internationale Vereinigung Vegetationskunde (1977), 273-283. Cramer, Vaduz.

Tüxen, R. 1979. Sigmeten und Geosigmeten, ihre Ordnung und ihre Bedeutung für Wissenschaft, Naturschutz und
Planung. Biogeographie 16: 79-92.

Tüxen, R. and Kawamura, Y. 1975. Gesichtspunkte zur syntaxonomischen Fassung und Gliederung von Pflanzengesellschaften entwickelt am Beispiel des nordwestdeutschen Genisto-Callunetum. Phytocoenologia 2(1/2): 87-99.

若松伸彦 - 菊池多賀夫. 2006. 奥羽山脈栗駒山に断片 的にみられるオオシラビソ林の立地環境について。 森林立地 48(1): 33-41.

山田麻子 - 大野啓一. 2000. 三浦半島における群植物 社会学的手法による植生景観の区分と評価. 植生 学会誌 17: 1-14

矢内晃子 - 許琴蘭 - 大野啓一. 都市緑地の構造解析 にかかわる景観生態学的研究.(投稿中)

横山秀司. 1995. 景観生態学. 207pp. 古今書院, 東京. 横山秀司 (編). 2002. 地生態学入門. $277 \mathrm{pp}$. 古今書院, 東京. 